CHAPTER 5

\title{
The Unfinished Picture: The Mystery of Rosa Bud
}

Pete Orford, University of Buckingham

Rosa Bud is one of Dickens's least understood heroines, and open to the widest range of interpretation and discussion. Of course, a great deal of this is owed to the incompletion of The Mystery of Edwin Drood (1870), and with it the uncertainty over Rosa's character arc and fate. There have been hundreds of theories presented since Dickens's death, which can be divided into two distinct categories of completions and solutions. A completion is a fully fleshed-out second half to Dickens's tale, while a solution is instead a discussion around Dickens's text. It is not necessarily the case that a completion is longer than a solution, as quite often writers have produced entire books discussing their theory for the end of Drood with detailed references to what they consider to be evidence. The key distinction is the range of focus: a completion has to take the entire narrative and cast of Dickens's book under consideration, while a solution can cherry-pick those aspects of the story deemed to be of most interest. It is perhaps also worth noting that solutions far outnumber completions.

Thus, while the business of trying to solve Drood is a popular one, it is primarily defined by the big questions: is Edwin dead or alive, who killed him, and who is Dick Datchery? Those proffering their solutions pay little attention to Rosa beyond a cursory mention of her husband-to-be. Even in completions,

\section{How to cite this book chapter:}

Orford, P. 2020. The Unfinished Picture: The Mystery of Rosa Bud. In: Bell, E. (ed.), Dickens After Dickens, pp. 101-116. York: White Rose University Press. DOI: https://doi.org/10.22599/DickensAfterDickens.f. Licence, apart from specified exceptions: CC BY-NC 4.0 
where authors have to account for Rosa's actions in the second half of their novel, it is clear their interest still lies more in the fate of Edwin and the identity of Datchery. Often completionists will embed studious layers of justification building up to the revelation of whether Edwin is dead or alive, but in the same works Rosa's fate is resolved with less attempt to prove its validity. In their conscious efforts to address the 'bigger' issues, completionists will in the process offer more casual judgements on other characters and plotlines. But even this is preferable to an absence of discussion, such as can often be seen in solutions. When Rosa does get a mention in these it is usually no more than a cursory consideration of who she will marry. Rosa has been slighted, to be sure. However, this is not a deliberately malicious act but rather an indication that, while Droodists recognise a controversy over Edwin's character arc, they do not see Rosa's fate as being nearly so debatable. Her story is not considered to be a mystery, yet in truth the variation in that fate in the hands of different authors tells us a great deal about their presumptions and the manner in which our assumed path for a Dickens heroine can change over the decades.

The importance of this lies in the scorn which is frequently, and unfairly, poured on Rosa for being either annoying or boring. Even Edmund Wilson, in his groundbreaking reappraisal of Drood, wrote derogatively that 'the characters that are healthy, bright and good - Rosa Bud, with her silly name, for example - seem almost as two-dimensional as colo[u]red paper dolls' (101). This argument will seek to show Wilson's mistake in dismissing Rosa as a paper doll, and argue that such an interpretation comes from only having the first half of the book and the importance we place upon the end of a story in determining the full depiction of a character. I shall begin by re-evaluating Rosa as she appears in Dickens's text, arguing for the potential blossoming of her character, before then looking at how others have proposed that development might take place. While most Droodists have tended to depict Rosa in the story's conclusion in a relatively conventional way, others have opted for a deliberately provocative reinterpretation of the character. This in turn is linked to the debate over whether any end to Drood should attempt to honour the intentions of Dickens, or instead divert from the original author altogether and move the story forward into new territory. As will be seen, Rosa's story, lurking on the fringe of Edwin's mystery, offers a far more intriguing glimpse into the myriad of possibilities awaiting the residents of Cloisterham.

\section{'Comically conscious of itself': Dickens's ambiguous heroine}

Even without the infinite potential for the character that comes from the unconfirmed ending, the Rosa that Dickens presents shows clear signs of a character ready to evolve. Wilson's dismissive interpretation of the character is easily explained by the early appearances of Rosa in which she is apparently very much a spoiled pet. But, even in her debut, Dickens warns us that there 
is more to the character than we are being told. We are introduced to Rosa not directly, but via her portrait. In Chapter 2 of Drood, Dickens describes a picture hanging on the wall of Jasper's room:

the unfinished picture of a blooming schoolgirl hanging over the chimneypiece, her flowing brown hair tied with a blue riband, and her beauty remarkable for a quite childish, almost babyish, touch of saucy discontent, comically conscious of itself. (There is not the least artistic merit in this picture, which is a mere daub; but it is clear that the painter has made it humorously - one might almost say, revengefully - like the original.) (14)

This picture is the perfect summary of Rosa's character. The description of Rosa as childish, saucy, and beautiful certainly seems to play into the dismissive reaction of Wilson and others. But Dickens also suggest her beauty to be 'comically conscious of itself', which hints at a deeper level of character behind the girlish façade. The true keynote of the description is 'unfinished'. It is unintentionally prophetic, of course, given the unfinished state of the book, but more immediately shows Dickens's depiction of Rosa at the start of the novel - a pettish, spoiled, not yet fully matured, character that is due to develop but is not finished yet.

Lynette Felber notes how portraits in Victorian literature provide 'a verbal representation of physical appearance that most conspicuously functions to establish character, and that seems to be the case here, with one important proviso: it is a bad picture of Rosa, lacking 'the least artistic merit' (471). The relationship between the physical appearance of Rosa and her character is complicated in this instance because the woman being described is not an accurate depiction of Rosa but Edwin's ill-attempted portrait of her, both humorous and revengeful. What we are therefore seeing, and the character we are having established, is as much Edwin's view of her as the true depiction. This is exacerbated by the picture's location hanging on Jasper's wall, which is explained as a sign of his affection for the artist, but of course recognised by the reader as part of Jasper's desire to possess the subject. Dickens's interpolation of Rosa's portrait into what is ultimately a scene between Jasper and Edwin shows both how she hovers over their relationship but also how she in turn is constantly defined and objectified by the two men. The viewers become as important, and under as much scrutiny, as the picture. In her consideration of portraiture in Victorian literature, Felber dwells on Lady Audley's Secret (1862), and the manner in which her portrait is viewed by George Talboys and Robert Audley, suggesting that 'The pleasure each individual man receives is different - and completes the portrait differently - but the juxtaposition of the two reactions illustrates the dual effect of the fetish' (474). Dickens's novel inadvertently presents the same distinction of two observers with two contrasting responses to the same picture. Edwin sees merely his own artistry, his little joke at Rosa's expense, with 
little thought for her, while Jasper meanwhile is condemned to only see Rosa via Edwin, to have her there in his sight, but through the distorted lens of his spoiled nephew.

That this picture which they look upon should be unfinished speaks volumes. It shows Edwin's lack of care and devotion that he cannot be bothered to complete the portrait. It also shows Jasper's desperation that he would display even a poorly sketched, incomplete picture of his love, given that it is all he can hope to ever have. Finally, it shows in both instances an incomplete understanding from either man of Rosa, that the idol they both gaze and muse upon is not the real thing, nor even a comprehensive account of her; It not only suggests Rosa is incomplete but moreover that there does not, at this early stage, exist a man who truly and completely knows her; that the depiction of her as childish and saucy is not so much a true reflection of her character but one defined by the gaze and opinions of others.

Even when Rosa does finally appear in person in the next chapter, Dickens further delays the moment by having her enter the room to Edwin 'as a charming little apparition, with its face concealed by a little silk apron thrown over its head' (26). That Dickens should even at this stage refer to Rosa as 'it' further identifies both her ambiguity and Edwin's failure to understand her as he sees this vision with little comprehension as to its gender. This can be further seen as an early indication of Edwin's own naivety and the lack of sexual frisson in their relationship that he sees the girl he is going to marry as this androgynous being. The headless apparition complements the bodiless head previously portrayed in Edwin's painting; Rosa is once again incomplete. The artfulness of Dickens's entrance for his heroine is that in drawing our attention to the concealment of her head, we revert to the earlier depiction of her face as our image of Rosa, and indeed Dickens does not correct it, as he never offers a direct description of Rosa herself. But, whereas in the previous scene the incompletion of Rosa's description was down to the inattention of Edwin, now the concealment is made of her own choosing. She throws her apron over her head deliberately in protest at the 'absurd' situation of her fellow schoolgirls being all in 'such a state of flutter' to gawp at her with her fiancé (25-6). Cloisterham's very name hints at the claustrophobic, enclosed nature of living in such a town, and Rosa is the star attraction, living in a goldfish bowl in which many stop to admire her. The apron is her early attempt to confound and deny the expectations of those who gaze upon her, to defy description and classification.

It is not only Rosa's appearance that proves to be so teasingly ambiguous. Her very name has attracted a variety of interpretation which in itself stands as testament to how differently Rosa has been understood by readers. Matthew McGuire suggests it is 'a metaphoric synonym of rosebud and the fragility it implies [of] the blushing English Rose' (61). The same idea is also voiced by Patricia Ingham, who points to several of Dickens's female characters with Rose for a name, and contextualises this within a pattern for his finding names from 'images ... frequently drawn from the natural world' (20). She argues that 
' $[\mathrm{w}]$ omen are concealed beneath generic flowers, conventionally sparkling water, hazily unspecific blossom. Or they take on the role of household pets' (21). This is Ingham's explanation for Edwin's nickname for her, which only he uses, of Pussy. To a modern reader it is hard to read this without a titter or two, and Natalie McKnight writes convincingly that this is entirely foreseen by Dickens. Far from being a corruption of an innocent name by later readers, McKnight argues that the sexual connotation of the name was well known in Dickens's time, and the idea that it was innocent reveals 'a tone-deafness to the language [which] also reflects the persistence of the stereotype about Victorian prudery' (58). She also notes that 'Rosa's real name, "Rosa Bud," is also a longstanding term and image for female genitalia' (55). Brenda Ayres had already noted what she felt to be the 'blatant' insinuations of Rosa's name, arguing that it 'immediately signals that the text will not be metaphorically obscure or complex in her gender description' (81). To her, the name 'Rose Bud' is itself descriptive of someone ready to be plucked and deflowered.

This sexual side of Rosa lies not only in her name but also in her actions. After those early descriptions, tantalisingly incomplete in their accounts, Dickens describes Rosa and Edwin upon a walk together,

off to the Lumps-of-Delights shop, where Rosa makes her purchase, and, after offering some to him which he rather indignantly declines), begins to partake of it with great zest: previously taking off and rolling up a pair of little pink gloves, like rose-leaves, and occasionally putting her little pink fingers to her rosy lips, to cleanse them from the Dust of Delight that comes of the Lumps. (30)

Ingham's Dickens, Women and Language (24-5) notes how 19th-century studies of physiognomy, such as Alexander Walker's 1834 work Physiognomy Founded on Physiology, identified the nose and mouth as animal organs, as opposed to the more intellectual organs such as eyes and ears, betraying our more basic desires. It is not without reason then to consider this hedonistic culinary moment to have sexual overtones as Rosa gives in to her sweet cravings. It also serves to show how Rosa is not the perfect Dickensian domestic heroine. As Ingham argues, 'the preparation of food is symbolic of the woman's essential abilities' (29). Whereas, for example, Mrs Cratchit's laboured creation of a Christmas feast confirms her perfection as a woman, Rosa is not preparing food but greedily and selfishly consuming junk food instead. In all of this she shows herself to be the antithesis of the good housewife.

The changing point in Rosa's character occurs in her breaking of the engagement with Edwin. This is an engagement arranged for them since children by their well-wishing fathers, now dead, that has been a chain around them, one more example of an adult dictating to Rosa. The moment she speaks the truth - and it is Rosa who speaks first - they immediately become less guarded, less petty, and better people for being open with one another: 
This pure young feeling, this gentle and forbearing feeling of each towards the other, brought with it its reward in a softening light that seemed to shine on their position. The relations between them did not look wilful, or capricious, or a failure, in such a light; they became elated into something more self-denying, honourable, affectionate, and true. (147)

The chapter's title of 'both at their best' is prescriptive in its congratulatory tone of the characters realising their potential to be better people, apart. The stage is set for Rosa to deviate from the plans laid down for her by the residents of Cloisterham. No longer defined by their expectations, she becomes immediately more 'honourably, affectionate, and true' rather than 'saucy' and 'childish' as when she was first introduced to the reader via her portrait. Ayres argues that Rosa 'courageously avoids a marriage to Drood that might follow the same disastrous course as Dora Copperfield's' (82) and sees it as a necessary step towards maturity. 'By not acting as a pet or a plaything', Ayres predicts that Rosa 'eventually will marry a young man and not a father type who will treat her like a toy' (82). Michael Slater agrees that the 'clear suggestion' is 'the reader will eventually see Rosa, inspired by love, rising above ... her own frivolity' (287). But, of course, we never have that marriage confirmed, as the story finishes halfway through, at which point others stepped in to correct the tale. As readers we leave Rosa in London, lodging with Miss Twinkleton in rooms belonging to the humorous but underused Billickin, dreaming of Tartar while mourning Edwin, and always fearing the appearance of Jasper. There are several characters who hold an interest in Rosa, but we are left ignorant of her desires. The earlier parting of Edwin and Rosa is a moment of great potentiality, but ultimately one without fruition. The death of Dickens has left Rosa without the culmination of her journey. She may no longer be a pet or plaything, but it remains to be seen whether she will marry a young man and how he will treat her. At this point, it has been left to the Droodists to provide Rosa a conclusion, with varying degrees of success.

\section{Budding romance: finding a man for Rosa}

Dickens's intentions were in fact made public in 1874 when Forster published the third and final volume of his biography of Dickens. In it he summarises his friend's plans for his final novel - Edwin is dead, Jasper did it, and 'Rosa was to marry Tartar, and Crisparkle the sister of Landless' (426). While not all were convinced by Forster's assertion of Edwin's death, there was relatively more consensus in terms of Rosa's fate. While academics argued in articles, what completions did appear after the 1870s nearly all followed Forster - W.E. Crisp (1914), Edwin Harris (1932), Charles Forsyte (1980), and Leon Garfield (1980) all marry Rosa off to Tartar. It is astounding that, at the same time Forster was 
being so roundly attacked for his supposedly false account, the perceived minor details of it were nonetheless being accepted. It shows to what extent Rosa's fate was of little consequence in many Droodists' eyes compared to that of the three men, Drood, Jasper, and Datchery. In presenting her in line with Forster's comments, the popular perception of Rosa switched from the foolish girl who changes her mind, to a young woman maturing and moving on from a platonic engagement to Edwin towards a sexual and deeper attraction to Tartar. It is an idea hinted at in Dickens's scene of Miss Twinkleton reading nautical tales aloud, of which Rosa takes opportunity to indulge in sailor-based fantasies:

As a compensation against their romance, Miss Twinkleton, reading aloud, made the most of all latitudes and longitudes, bearings, winds, currents, offsets, and other statistics (which she felt to be none the less improving because they expressed nothing whatever to her); while Rosa, listening intently, made the most of what was nearest to her heart.... (254)

But Tartar did not always get the girl. In the case of screen adaptations, he never even showed up. The simple process of adapting the text for performance meant the familiar act of cutting characters; Tartar, however much he may have been embraced in written solutions as the man for Rosa, nonetheless is only a bit part in the fragment we have from Dickens, and therefore one of the easiest to cut. It is a question of ratio: Tartar appears for the first time in the fifth monthly number of Drood. Had the book been finished he would thus have been present for seven out of 12 numbers (over half the book), whereas in its unfinished state he appears in only two out of six numbers (merely a third). However much we can argue for his potential importance, from the perspective of scriptwriters adapting the text in front of them, Tartar is a minor character. The story has been adapted for screen eight times: on film in 1911, 1912, 1914, 1935, and 1993, and for television in 1952, 1960, and 2012. The UK television series of 1960 for ITV is the only adaptation to include Tartar. In the other adaptations the heroic vacuum left by Tartar's absence demands another man to step forward and fill the void, and of the possible contenders it is Neville who is the popular choice to step forward and assume the romantic lead.

In MGM's film of 1935, Neville is not only Rosa's dream man but the leading hero of the film, disguising himself as Datchery to clear his own name. In Mayfair Entertainment's 1990 film Crisparkle does much of the heroics, but Neville still steps in at the end as a romantic foil for Rosa. What proves dissatisfying in this interpretation is the impact it has on Rosa's character and her motivations during the breaking of the engagement with Edwin. She meets Neville before breaking the engagement with Edwin, whereas Tartar is unknown to her until afterwards. Thus, if she loves Tartar, then her break with Edwin is an entirely mature decision based on what is best for Rosa herself. But, if she is in love with Neville, the break becomes informed not by her internal growth as a character 
but by the external impulse of a new man who has stolen her affections. Falling in love with Neville robs Rosa of the degree of agency and self-awareness which Dickens points towards in her parting from Edwin. It is the sailor who stands as the choice for a more mature Rosa, a young woman making her own decisions in the world rather than being dictated by giddy, changeable affections for men. Though Slater talks of a 'paucity of examples of a woman morally guiding and spiritually inspiring or redeeming a husband or a son' (311), it is significant that Rosa is not the one to redeem Tartar, who instead represents much of what the ideal domestic goddess is supposed to offer to a male protagonist. Dickens informs us that the sailor's chambers are already 'the neatest, the cleanest, and the best-ordered chambers ever seen under the sun, moon and stars' (236), and his time with Rosa places him in the position of offering stability and inspiration to Rosa. Tartar needs no redemption; he is the morally guiding and spiritually inspiring househusband to redeem her.

There is however a third popular candidate for Rosa's husband to challenge this: Edwin Drood. In the 1870s, especially when Forster's account was either unpublished or still circulating, Tartar proved less popular a choice than Edwin. Slater's earlier projection for Rosa rests on the idea that her rising 'above her own frivolity' will be 'like Bella before her' (287), and certainly the precedent of Bella Wilfer in Our Mutual Friend has been readily noted and used as a means of projecting her plot onto Rosa's. As early as 1871 the comparison was being made, in The Dublin Review, not only with the existing text of Drood but as a means of speaking with certainty on the content of the missing conclusion:

'The Mystery of Edwin Drood' is, in some respects, a singular repetition of its immediate predecessor. In 'Our Mutual Friend'; and in 'Edwin Drood,' we have a young lady and a young gentleman betrothed to one another by other people, and very doubtful of the wisdom of the arrangement. In both, the young man disappears, the young lady believes him to be dead, and is affectionately guarded by his confidential friend (in each case an amiable eccentric) who is the only person in possession of the secret. Julius Handford and Edwin Drood, Bella Wilfer and Rosa Bud, Mr Boffin and Mr Grewgious, lay analogous parts in these stories... . (329)

Early solutions, keen to prove the mystery had a twist in the tale, resurrected Drood, and having done so married him off to Rosa after all. In doing so the writers conformed to social expectations of marital agreements rather than championing the young people's decision to defy their parent's wishes. A number of the early completions hint heavily at how foolish Rosa and Edwin had been when they broke off their engagement - a direct contradiction of Dickens's emphatically positive description of it. T.P. James, in his 1874 completion, writes a glowing reference for the sagacity of fathers as Edwin both announces his love for Rosa and acknowledges her reciprocal feelings: 
Our fathers could look into the future after all, and notwithstanding we tried so hard to go contrary to their last wishes, affliction came with its sharp teeth, and, tearing away the weeds of frivolity that hid our hearts from us, disclosed that which we should never have known else - that we could love each other dearly... . (461)

In her 1878 completion, Gillian Vase offered the same conclusion of Edwin and Rosa overcoming their youthful folly to marry at last, but she elongated the maturing process of the couple. No sooner does Edwin return - alive - but Rosa sends him away to prove his love is not just a passing fancy, to which Edwin readily agrees:

Let me earn your love, sweetest! I do not deserve it yet, I know. The remembrance of the careless indifference with which I treated you, when I was a foolish boy who did not know your worth, is the bitterest drop in my cup of sorrow. Let me work for you, prove myself worthy of you, if that be possible... . (3:273)

Years then pass, such an interim that allows Helena and Crisparkle to have a child before Edwin eventually returns, and in that time Rosa begins to regret sending Edwin away:

She had bid him remain her brother, and now she is hurt, angry, mortified that he does her bidding. She had warned him to approach no nearer, and now her heart sinks low because he does not cast her warning to the wind. An enigma? She and all her sex? Yes, truly, not only to Mr Grewgious, but to her own puzzled heart! (3:324)

Not only is Rosa depicted as a foolish young thing when she breaks from Edwin but moreover someone who does not know her own heart. Again, this utterly undoes the power of the original breaking of the engagement in Dickens's text, robbing the pair of their moment of maturity and rewriting it as a false impression conceived by immaturity and lack of self-knowledge.

The irony is that on first consideration we might think that accepting Forster's comments and marrying Rosa off to Tartar could be argued as the most conventional ending for her, if we take it to be what Dickens intended. But, in actuality, pairing Rosa to Tartar challenges a great deal of the conventional ideas of this childish pet; it allows her the opportunity to evolve and transform into a woman of her own mind and choice. In contrast, attempts to buck Forster's suggestions actually result in a less exciting presentation of Rosa. It undoes what Dickens sets up in the early text of Drood and forces the character back into the constraints of a silly, foolish thing who does not know what is best for herself. If anything, marrying Rosa to Edwin, or Neville, is less inspired than allowing her to aspire to Tartar. She becomes either 
a damsel in distress or a poster girl for respecting the far-seeing wisdom of parents.

\section{Sub Rosa: unconventional pairings and deviations}

The majority of proposed endings to Drood see Rosa married off to Tartar, Neville, or Edwin. It is the conventional choice in terms of popularity, then, but conventional also in that each time the decision to marry her to one of those three is perceived, or intended, as uncontroversial. Either the writer is aiming to present what Dickens intended, or the reader's attention is diverted elsewhere to more radical decisions in the solution. Occasionally, however, the culmination of Rosa's plot arc is more unusual. The decision to divert from the majority is often done deliberately and mischievously in order to challenge other solutions, turn them on their head, or simply make this new solution different from what has gone before. Other times it remains, like so many others, as an earnest projection of what the author believes Dickens intended. It should however be noted that in almost all instances these different outcomes for Rosa are linked not to her character specifically but tend to be the side effect of new plotlines and interpretations of other characters. For example, Henry Morford's 1871 completion, John Jasper's Secret, makes no controversial changes to Rosa directly, even concluding the book with Tartar as her husband (three years before Forster would make Dickens's intentions for this public). However, he radically changes the character of Grewgious in such a way that has an impact on the portrayal of Rosa. Almost every other completion and solution has interpreted Grewgious as a father figure to Rosa, reading his enduring love for her mother as a means of making her into his surrogate daughter - the child he might have had. Morford interprets Grewgious's affections quite differently, assuming that, as he loved the mother, so too he will be attracted to the daughter. Grewgious not only loves Rosa but at times believes that she loves him too.

For one instant a mad, delicious thought ran through him, making every pulse tingle, sending the blood like a torrent to cheek and brow, and lifting the sad, patient old heart so high as to choke utterance. What if - - - The other words of the mental sentence were never supplied, for before they could be shaped, came the one crushing word, forming a sentence in itself: Impossible! and behind it rang out two others, used so many times before, and forming another pregnant sentence: Old Fool! Then the rebellious heart sank back to its proper place, the momentary madness passed from face and frame, the throat ceased choking, and the voice returned.... (137)

He becomes a less malevolent mirror of Jasper, with the key difference being that, as soon as he realises her affections lie elsewhere, he gracefully steps back 
having never uttered a word to her of it. With Tartar marrying Rosa, and the resurrected Edwin marrying Helena, Grewgious thus stands with Neville and Crisparkle as what Morford describes as 'the trio of the disappointed' who become ' $[s]$ omething more: the trio of the brave, patient and determined under that disappointment most difficult to bear of all laid upon humanity' (217). Grewgious, with the others, becomes a noble and romantic figure to be admired for what is set to be an everlasting but unrequited romantic love for Rosa. She is unaware of any of it, the innocent cause of another man's pain. Her unintentional cruel beauty claims both Grewgious and Jasper as its victims, shifting the blame from the inappropriateness of their affections onto the object of them. Rosa becomes a femme fatale, or rather an infant fatale, unwittingly stirring feelings in older men. By redefining Grewgious's role it necessarily impacts on Rosa's portrayal too, stripping her of agency and awareness and objectifying her into something for men to lust over.

A more dramatic rewriting of Rosa's fate comes in the rebranding of Jasper as hero. As the novel's antihero, Jasper is clearly the character of most interest to the reader, and as such some have tried to develop the character into someone we can sympathise with. Felix Aylmer's bizarre 1964 solution The Drood Case posits that Jasper never intended to kill Edwin but was in fact trying to save him from a family curse inherited from Edwin's father. Years earlier, Aylmer posits, Drood Senior 'was in Egypt in 1815' (47), where he seduced a girl, their illegitimate child being Jasper. The girl's father challenged Drood Senior to a duel, in which Rosa's father was his friend's second. After winning the duel, Drood Senior, 'whether in self-defence or from ungovernable passion', carries on 'to attack a second member of the family', with Bud Senior intervening to avert 'a second tragedy' (56). The outcome of this is that Drood Senior is now involved in a blood-feud' while simultaneously 'Bud [Senior] would have placed the Muslim family in his debt' (56). Thus Drood Senior is condemned to die while Bud Senior is placed under a protective blessing, the one cancelling the other out: this is why Rosa is engaged to Edwin, so that, when the children inherit their fathers' curse and blessing, the one will once again neutralise the other. Only Jasper knows the truth, and for love of his nephew he ignores his own feelings for Rosa to ensure the marriage goes ahead and Edwin is saved from the hordes of Egyptian assassins bent on his destruction (it bears mentioning that Aylmer, like many Droodists before him, insists that his analysis is 'based exclusively on evidence' that he has found within the pages of Drood [4]). When the assassins nearly get Edwin, he mistakenly believes it was Jasper, so that the whole of Cloisterham believe Jasper to be a villain, leading to a deathbed scene in which Jasper, fatally wounded after the most recent attack, admits all to Edwin and Rosa, who are now in love and feel wretched over their horrendous misreading of Jasper's character. Jasper dies, having been 'hounded to death by the misinformed and uncharitable treatment of the community in which he lives', to be vindicated by 'the heartbroken penitence of Rosa' (171). It is a tortuous and convoluted rewriting of the original text, and one that dangerously places 
Rosa's stalker as a wretched, misunderstood hero. It is a vindication of every man who ever refused to give up on a woman, and a slap in the face for every woman who has ever tried to explain that no means no. Aylmer even proposes 'evidence that Dickens originally intended to bring Jasper and Rosa together in the end' (169) by arguing that the pair are fictionalised versions of Dickens and Ellen Ternan. He does this not to suggest unsavoury tones in Dickens's affair but rather to legitimise Jasper's prolonged pursuit of Rosa. In Aylmer's hands Rosa herself is reduced to an apology on behalf of women, and the reader, for their hasty judgement on men like Jasper.

Despite his hinting of 'evidence', ultimately Aylmer keeps Jasper's love for Rosa unrequited, in order to make his hero the purer and more angelic in his celibacy. But others have drawn on Jasper's darkness to suggest a more carnal desire not only from him for Rosa, but from Rosa for him. Jasper becomes Rosa's id, the hidden side of her that she tries to keep down while acting in such ways as Victorian manners dictate. In Vase's 1878 completion, Rosa owns and recognises the connection between herself and Jasper, terrifying as it is to her. When he confronts her alone, at a point when she still believes Edwin to be dead, she submits to the connection they have, however perverse it may be:

Let us be patient with one another! Let us speak like reasonable beings over our hard fate! A strange and unaccountable destiny has ordained that you should love me ... and the same destiny has ordained that I - that I should not be able to return the feeling ... I am willing ... to meet you halfway, and to bear my share of the suffering to which we are condemned. I promise you, if you will abandon your pursuit of me - which makes me wretched, and which can be productive of no other result to you - by my most sacred word and honour, to remain single all my life, to accept no man as a suitor or a husband, and, in this way, to give you no reason for hatred or jealousy of another; only begging you to leave me undisturbed to my solitary life and lonely fate to which your love will have consigned me. (288-9)

It is simultaneously a moment of submission and ownership, a proactive decision on Rosa's part to end this, but in such a manner that will forever tie her to Jasper. The fatality of the moment is emphasised in the continuation of the scene where Vase elevates Jasper to gothic monster and relegates Rosa to the gothic damsel in distress. Surprised in their meeting by the distant approach of Tartar and Crisparkle, Jasper grabs Rosa and tries to escape, in response to which she faints.

With sudden impulse, he sprang up the bank of the river, and standing upon its brink, looked back towards his pursuers, and then down upon the face resting on his shoulder. 
He had never seen it so beautiful, he fancied. No, not even when flushed with health and happiness. Her bright luxuriant hair hung disheveled over his arm and framed in a face, pale as death, and chaste and pure as marble.

Tenderly, almost reverently, he stroked back the soft, clinging curls, and let his eyes feast for the last time in contemplation of her beauty beauty which had brought them both to this - to this.

Then he bowed his head, and pressed convulsively his burning, passionate lips on her pure cold ones; raised her high in the air in full sight of his pursuers, who stood still, paralysed with terror; clasped her to his heart again; and with a wild cry of defiance and exultation, sprang with her into the river. (294-5)

Rosa and Jasper become bound together. Jasper becomes another Heathcliff, with shades of Quasimodo, nurturing a love for Rosa despite her revulsion, so that we are unclear whether he is the villain for his pursuit of her, or she is the villain for her refusal to accept him. In Morford, Aylmer, and Vase's interpretations Rosa becomes either passive and unaware or capricious in her withholding of affection for he who most admires her. Others have averted this by giving her full ownership of Jasper's affections and imagining a love affair blooming between the two. It is perhaps not coincidental that these solutions are intentionally erotic. Roman de la Rose's The Blossoming of the Bud and Laurie Love's Mr Jasper's Cadenza allow Rosa to give in to her darkest desires and complete her sexual maturing. In doing so she faces concern and condemnation from townsfolk who increasingly suspect Jasper (though both cases argue for his innocence of Edwin's death). Both Rose and Love's solutions are part wish-fulfilment on the authors' part - Love in particular notes a great debt to the portrayal of Jasper by Matthew Rhys in the 2012 BBC adaptation 'clad in black, tightly buttoned, dark features, dark hair, repressed lust' (author's note) for stirring her imagination and attraction to the character - but also a redefinition of Rosa for the modern age. No longer bound by Victorian morality, she dismisses the other men in favour of the most interesting character in the book. Good manners and socially acceptable marriages are rejected in favour of lust and physical gratification. Jasper becomes the choice for a Rosa who is older and wiser, who sees beyond what society expects to find the person who, against all odds, is the right personal choice for her.

The final radical choice for Rosa is to reject men altogether. Helena Landless's fiercely defensive stance over Rosa in Dickens's text - her 'wild black hair' is said to fall 'protectingly over [Rosa's] childish form', while 'a slumbering gleam of fire in [her] intense dark eyes' is 'softened with compassion and admiration' (71) - has proved ripe for speculation in modern criticism, with Holly Furneaux pointing out the homoerotic nature of their relationship: 'The foreignness that renders Jasper's intense feeling for his nephew visible as homoeros, has continuities in the relationship that the repatriated Helena Landless enjoys with the 
English Rosa' (166). Yet, even in an age of online fanfiction and the wide range of interpretations this encourages, little has been done to flesh out the idea of a lesbian Rosa. The closest is in Rupert Holmes's 1985 musical, in which Edwin is played by a woman. Holmes positions Dickens's text as a performance in a Victorian music hall, with a subsequent degree of meta-theatre and self-awareness. In one sense the casting of a woman in the role of Edwin confirms his sexual incompatibility with Rosa (by Victorian society standards), and yet, during the breaking of the engagement, the song they perform, 'Perfect Strangers', is the closest that Holmes's adaptation gets to a romantic duet.

Rosa: If we were perfect strangers

How perfect life could be!

Drood: I'd know if I adore you

You'd know if you love me... (40)

It is not a total denial of their love for one another but a recognition that the arrangement of their marriage without their consent has robbed them of the chance to know what their true feelings for one another are. The duet's final couplet, 'If we'd been perfect strangers/I might have loved you perfectly' (40), sung in unison, hints at a love that under different circumstances might almost be, indeed, perfect - and it is sung by two women. Yet, the show's biggest impact on opening up Rosa's interpretation is in its famous ending, in which audiences vote for the solution of their choice. They are allowed to decide who kills Edwin and who is Dick Datchery, and to pick one male and one female to marry one another. As Holmes himself has noted, this usually leads to audiences deliberately picking the most inappropriate or unexpected pairing: he pronounces himself 'pleased to say that during its entire run on Broadway and in Central Park, no audience ever elected Jasper as Murderer' (71). On stage Rosa has been paired to Jasper, Crisparkle, Bazzard, Durdles, or even Deputy. It is an instinctive human reaction, when given the choice, to try to be original and unconventional for the fun of it. Holmes's musical has allowed audiences not to vote for the Rosa they think Dickens intended but to deliberately vote against that and create a new Rosa beyond the imagination of her creator.

This defiance of Dickens was continued in the aforementioned 2012 BBC adaptation. Despite the audience's appreciation of Rhys's Jasper, Rosa in the hands of screenwriter Gwyneth Hughes had an entirely original finale planned: she married no one. Hughes called it her 'great pleasure to rescue 17-year-old Rosa from the Dickensian fate of an early disastrous marriage' (279). Dickens's apparent plan for his heroine to mature has taken on a new meaning as the plot itself has matured in its attitudes in the century and a half since it was written. Hughes's completion reflects the attitudes of the time it was written rather than respecting the attitudes of the 19th century when it began. Hughes's mention of a 'Dickensian fate' means that celebrating Rosa goes hand in hand with demonising Dickens: it confirms the worst prejudices about his female characters by deliberately setting this new Rosa up as a demolition of the original. It unintentionally resurrects the old prejudices of Dickens's failings in writing female 
characters, but ironically it does so in relation to one of his few women who might actually be poised to break the mould. Hughes's singleton Rosa is a Rosa for the modern age, but (assuming Forster's summary to be correct) Dickens's married Rosa, dismissing the wishes of her parents to choose for herself, is just as bold a step forward for its time, if not ours. Rosa had the potential to be something new in Dickens's writing, and had that plotline been confirmed I believe it would have had a greater impact on our understanding of Dickens than the fate of Edwin or the identity of Datchery ever could.

\section{The end crowns all: the importance of Rosa's choice}

It will have been observed by now that the predominant focus has been on Rosa's endpoint in the story, specifically whom she marries (if she marries). It is not the most diverse plot projection, but it is telling. Those working out their theories on Drood frequently start from the end and work backwards. For an author penning a completion, characters become defined by where they have to end up. If they have decided that Rosa is going to marry Edwin, then they will by necessity devote their characterisation of Rosa to building towards this end. Depending on her suitor she will become rebellious or regretful, modest or mischievous, feisty or feeble. The end infers the journey taken and determines the character's arc accordingly. But, more than this, it reflects our own preoccupations and presumptions at the time at which each completion is written. The endings written for Rosa are remarkably diverse: meekly acknowledging the wisdom of her parents and accepting at last their choice of Edwin; leaving Cloisterham to find romance with a sailor in the big city; dismissing social expectations completely for carnal pleasure with the man accused of her fiancés murder; or just giving up on men altogether. All of this speaks of the potential within ourselves to shape and reorder Dickens to suit our needs and desires. Without that definite end before us in black and white, Rosa's choice is our choice. The ending we choose for her - the ending we want for her - reflects not only our own ideas of what constitutes a Dickensian heroine but moreover what we demand and expect as a satisfactory resolution for women characters. It mirrors the neo-Victorian afterlives of Miss Havisham explored in Chapter 4, where the ending is the foregone conclusion. In contrast to the tragedy of Miss Havisham that must be played out repeatedly, each generation adapts Rosa to meet their expectations. Her fluidity, hinted at in Dickens's writing and unintentionally expanded by Drood's unfinished status, has allowed her to become, in many respects, a heroine for all.

\section{Works cited}

Aylmer, Felix. The Drood Case. Rupert-Hart-Davis, 1964.

Ayres, Brenda. Dissenting Women in Dickens's Novels. Greenwood Press, 1998. 
Crisp, W.E. The Mystery of Edwin Drood. London, 1914.

De La Rose, Roman. The Blossoming of the Bud. www.fanficton.net. 11 Mar. 2012. https://www.fanfiction.net/s/7755271/6/The-Blossoming-of-the-Bud. Accessed 10 Nov. 2018.

Dickens, Charles. The Mystery of Edwin Drood. Edited by David Paroissien. Penguin, 2002.

Felber, Lynette. 'The Literary Portrait as Centerfold: Fetishism in Mary Elizabeth Braddon's Lady Audley's Secret.' Victorian Literature and Culture, vol. 35, 2007, pp. 471-88.

Forster, John. The Life of Charles Dickens, Volume Three. Chapman and Hall, 1874.

Forsyte, Charles. The Decoding of Edwin Drood: Fact-fict-ion Solution to a Classic Problem. Victor Gollancz Ltd, 1980.

Furneaux, Holly. Queer Dickens: Erotics, Families, Masculinites. Oxford UP, 2009.

Garfield, Leon. The Mystery of Edwin Drood. Andre Deutsch, 1980.

Harris, Edwin. John Jasper's Gatehouse. Mackays Ltd, 1932.

Holmes, Rupert. The Mystery of Edwin Drood Performance Script, 1985.

Hughes, Gwyneth. 'Afterword', in Charles Dickens, The Mystery of Edwin Drood. BBC Books, 2012, pp. 275-9.

Ingham, Patricia. Dickens, Women and Language. Harvester Wheatsheaf, 1992.

Morford, Henry. John Jasper's Secret. London: Wyman and Sons, 1871.

James, Thomas Power. The Mystery of Edwin Drood Complete. T. P. James, 1874.

Love, Laurie. Mr Jasper's Cadenza. www.fanfiction.net. 15 Jan.-19 Feb. 2012. https://www.fanfiction.net/s/7743057/1/Mr-Jasper-s-Cadenza.

McGuire, Matthew. The Role of Women in the Novels of Charles Dickens. Minerva Press, 1995.

McKnight, Natalie. “'A Little Humouring of Pussy's Points!”; or Sex - the Real Unsolved Mystery of Edwin Drood. Dickens Quarterly, vol. 30, no. 1, 2013, pp. 55-63.

Slater, Michael. Dickens and Women. J. M. Dent and Sons, 1983.

'Two English Novelists: Dickens and Thackeray'. The Dublin Review, vol. 17, no. 32, 1871, pp. 315-50.

Vase, Gillian. A Great Mystery Solved: A Sequel to The Mystery of Edwin Drood, 3 vols. Remington and Co., 1878.

Wilson, Edmund. 'Dickens: The Two Scrooges', The Wound and the Bow: Seven Studies in Literature. Riverside Press, 1941, pp. 1-104. 